\title{
Efficacy and Toxicity of Factor Xa Inhibitors
}

\author{
Maryna Bondarenko ${ }^{1}$, Christophe Curti ${ }^{2,3}$, Marc Montana ${ }^{3,4}$, Pascal Rathelot ${ }^{2,3}$, Patrice Vanelle ${ }^{2,3}$ \\ ${ }^{1}$ Assistance Publique - Hôpitaux de Marseille (AP-HM), Service de la pharmacie à usage intérieur de l'hôpital Nord, \\ Marseille, France, ${ }^{2}$ Aix-Marseille Université, CNRS, Institut de Chimie Radicalaire ICR, UMR 7273, Laboratoire de \\ Pharmaco-Chimie Radicalaire, Marseille, France, ${ }^{3}$ Assistance Publique - Hôpitaux de Marseille (AP-HM), Service \\ Central de la Qualité et de l'Information Pharmaceutiques, Marseille, France, ${ }^{4}$ Assistance Publique - Hôpitaux de \\ Marseille (AP-HM), Oncopharma, Marseille, France.
}

Received, December 18, 2012; Revised, February 4, 2013; Accepted, February 13, 2013; Published, February 15, 2013.

\begin{abstract}
Venous thromboembolism (VTE) is a serious disease that is often neglected, and effective and safe antithrombotic treatments are a public health priority. New antithrombotics such as rivaroxaban, apixaban, betrixaban, edoxaban, darexaban, TAK-442, LY517717, eribaxaban, otamixaban are being developed to overcome current therapeutic limitations. The new oral anticoagulants and parenteral otamixaban are under evaluation in clinical trials for VTE treatment, for VTE prevention in orthopedic surgery, for stroke prevention in patients with atrial fibrillation and for cardiovascular event prevention in patients with acute coronary syndrome. These antithrombotic agents directly and selectively inhibit factor $\mathrm{Xa}$, and do not require coagulation monitoring and dose adjustment. Several of these drugs have shown promising results and have the potential to either replace or act as alternatives to traditional anticoagulants (heparins, vitamin $\mathrm{K}$ antagonists).
\end{abstract}

This article is open to POST-PUBLICATION REVIEW. Registered readers (see "For Readers") may comment by clicking on ABSTRACT on the issue's contents page.

\section{INTRODUCTION}

Venous thromboembolism (VTE), including deep vein thrombosis and pulmonary embolism, causes significant morbidity and mortality. There are more than 600,000 symptomatic venous thromboembolic events and 300,000 deaths per year in the USA (1), and more than one million thromboembolic disorders including 500,000 venous thromboembolic events leading to death each year in the European Union (2). Major orthopaedic surgery of the lower limbs is associated with an increased risk of VTE, responsible for $50 \%$ of asymptomatic thromboembolic events and between 5 and $15 \%$ of clinical thromboembolic events (3). Atrial fibrillation is the most common arrhythmia and a major risk factor for ischemic stroke. It affects approximately $2 \%$ of the general population and $10 \%$ of people over 75 years of age, and entails major health expenditure $(4,5)$.

The annual cost of health care for VTE is approximately from $\$ 7,594$ to $\$ 16,644$ per patient in the USA, depending on whether there is primary or secondary diagnosis of deep vein thrombosis and pulmonary embolism (6) Despite the costs of thromboprophylaxis, the prevention of venous thromboembolic events following major orthopaedic surgery is considered more cost-saving than its absence (7). Thus, VTE is a major public health problem whose prevention and treatment $(8-10)$ needs to be both effective and safe with respect to bleeding, particularly in high-risk patients.

Conventional antithrombotic therapy comprises unfractionated heparin (UFH), the low molecular weight heparins (LMWHs), the synthetic pentasaccharide fondaparinux and the vitamin $\mathrm{K}$ antagonists (VKAs). All these agents have a potential bleeding risk, and their limitations of use are well known (Table 1) (1012). To compensate for the drawbacks, new anticoagulants with characteristics similar to those of an "ideal" anticoagulant have been developed (Table 2) (13-16), namely rivaroxaban, apixaban, betrixaban, edoxaban, darexaban, TAK-442, LY517717, eribaxaban, otamixaban. Dabigatran (Pradaxa ${ }^{\circledR}$, Boehringer Ingelheim) a new orally direct thrombin inhibitor is also available. A wide variety of indirect comparisons studies of FXa inhibitors versus dabigatran have been performed, and have found different results.

Correspondance Author: Patrice Vanelle, Aix-Marseille Université, UMR CNRS 7273, Laboratoire de PharmacoChimie Radicalaire, faculté de pharmacie, 27 boulevard Jean Moulin, 13385 Marseille, cedex 05, France. E-Mail : Patrice.vanelle@univ-amu.fr 
For stroke prevention in atrial fibrillation several studies suggested that dabigatran $150 \mathrm{mg}$ is superior to rivaroxaban for some efficacy endpoints (17-19) and is the most cost-effective therapy (20). In the same indication, another study with subgroup analysis has found no statistically significant differences in efficacy between apixaban and dabigatran or rivaroxaban (21). Furthermore, several authors emphasize that such indirect comparisons should be used only to generate hypotheses, which need to be tested in a clinical trial comparing the FXa inhibitors and dabigatran directly (18). Because it plays a central role in the coagulation cascade, activated factor X (FXa) appears an interesting target in the search for new agents.

New antithrombotic agents selectively and directly inhibit FXa by binding to the active site of factor Xa. Antithrombin-independent inhibitors have the potential to inhibit FXa when it is free and clot-bound, as well as the activity of prothrombinase. This leads to interruption of the intrinsic and extrinsic coagulation cascade pathways and thus to inhibition of thrombin formation and thrombus development (Figure 1) $(22,23)$. With the exception of parenteral otamixaban, these synthetic low molecular weight FXa inhibitors are orally active. The new drugs present a low variability in pharmacokinetic and pharmacodynamic profiles and more stable anticoagulant activity over time, which means that biological monitoring of haemostasis and dose adjustments are not required $(13,22,23)$.

Direct FXa inhibitors are under evaluation in clinical trials for the treatment of VTE, the prevention of VTE in orthopaedic surgery, the prevention of systemic thromboembolism in atrial fibrillation and of cardiovascular events in acute coronary syndrome.

\begin{tabular}{|c|c|c|c|c|}
\hline VKAs & UFH & LMWH & Fondaparinux & Dabigatran \\
\hline Slow onset of action & Parenteral administration & $\begin{array}{l}\text { Parenteral } \\
\text { administration }\end{array}$ & $\begin{array}{l}\text { Parenteral } \\
\text { administration }\end{array}$ & Oral administration bid \\
\hline $\begin{array}{l}\text { Unpredictable } \\
\text { anticoagulant effect and } \\
\text { patient response }\end{array}$ & $\begin{array}{l}\text { Unpredictable } \\
\text { anticoagulant effect due } \\
\text { to unspecific binding }\end{array}$ & $\begin{array}{l}\text { Contraindication in } \\
\text { patients with severe } \\
\text { renal insufficiency }\end{array}$ & $\begin{array}{l}\text { Contraindication in } \\
\text { patients with severe } \\
\text { renal insufficiency }\end{array}$ & $\begin{array}{l}\text { Contraindication in } \\
\text { patients with severe } \\
\text { renal insufficiency }\end{array}$ \\
\hline $\begin{array}{l}\text { Narrow therapeutic } \\
\text { window }\end{array}$ & $\begin{array}{l}\text { Potential for severe } \\
\text { heparin-induced } \\
\text { thrombocytopenia }\end{array}$ & $\begin{array}{l}\text { Risk of heparin- } \\
\text { induced } \\
\text { thrombocytopenia }\end{array}$ & & $\begin{array}{l}\text { Multiple drug } \\
\text { interactions }\end{array}$ \\
\hline $\begin{array}{l}\text { Multiple food and drug } \\
\text { interactions }\end{array}$ & $\begin{array}{l}\text { Coagulation monitoring } \\
\text { (aPTT or anti-factor Xa } \\
\text { activity) }\end{array}$ & & & $\begin{array}{l}\text { Intestinal absorption } \\
\mathrm{pH} \text { dependant with low } \\
\text { bioavalability }(6 \%)\end{array}$ \\
\hline $\begin{array}{l}\text { Regular coagulation } \\
\text { monitoring (INR) and } \\
\text { dose adjustment }\end{array}$ & $\begin{array}{l}\text { Regular monitoring of } \\
\text { platelet count }\end{array}$ & & & \\
\hline
\end{tabular}

Table 2. Characteristics of an "ideal" anticoagulant.

Oral administration

Rapid and predictable action

Wide therapeutic window

No requirement for routine coagulation monitoring and dose adjustment

High efficacy-to-safety index

Minimal interactions with food and other drugs

Use in patients with severe renal insufficiency, hepatocellular insufficiency, in old age and with extreme body weight Availability of an antidote 


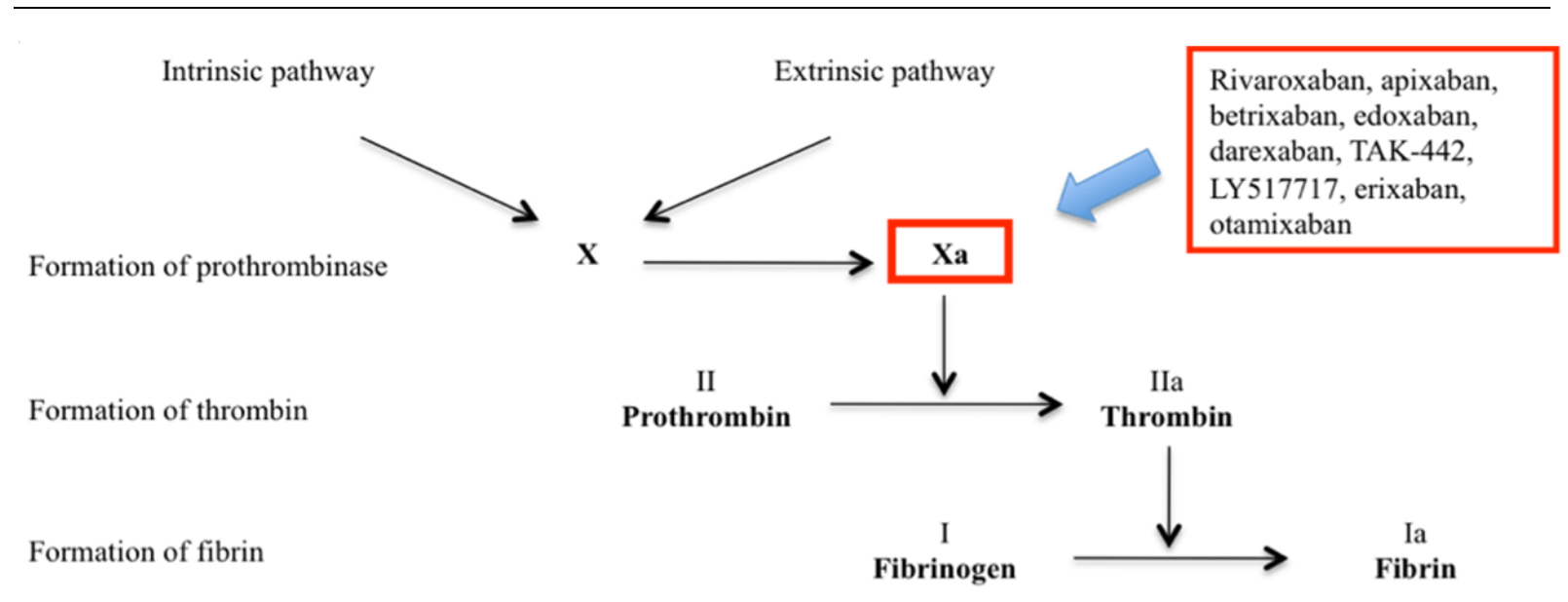

Figure 1. Schematic representation of the coagulation cascade and site of action of the novel anticoagulants.

Many of these drugs appear promising as new therapeutic options, even as alternatives to conventional antithrombotic therapy including heparins and VKAs.

The purpose of this review is to describe the direct FXa inhibitors and where they stand in relation to the antithrombotic therapies currently used in clinical practice. This paper focuses on new anticoagulants in clinical development, their efficacy and safety. We highlight two drugs that have recently obtained marketing authorisation.

\section{Drugs which have Obtained Marketing Authorization}

\section{Rivaroxaban}

Rivaroxaban (Xarelto ${ }^{\circledR}$, Bayer / Johnson \& Johnson) is the oral direct factor Xa inhibitor that has been investigated the most thoroughly. Based on the results of four dose studies (ODIXa program) and four clinical studies (RECORD program), it has recently been approved at a dosage of $10 \mathrm{mg}$ taken once daily for the prevention of venous thromboembolic events after scheduled orthopaedic surgery of the lower limbs (total hip or knee replacement) $(24,25)$. These studies demonstrated the superior efficacy of rivaroxaban compared with enoxaparin in thromboprophylaxis for major orthopaedic surgery, and tolerance of rivaroxaban was not different or lower in terms of major bleeding, elevation of liver enzymes or incidence of cardiovascular events $(25,26)$. Rivaroxaban is contraindicated in patients with severe hepatic insufficiency and it is not recommended in patients with severe renal insufficiency. There are a number of known drug interactions with potent inhibitors and inducers of cytochrome P450 3A4 due to a partial metabolism of rivaroxaban by this cytochrome (24).

Two dose studies, the ODIXa-DVT (27) and EINSTEIN-DVT studies (28), on the treatment of VTE suggest that the initial treatment of VTE requires more aggressive dosing, whereas a subsequent dose reduction maintains the initial efficacy while decreasing the risk of bleeding. Thus, the optimal dosage regimen used in phase III studies is $15 \mathrm{mg}$ twice daily for 3 weeks followed by long-term treatment with $20 \mathrm{mg}$ once daily (29).

The EINSTEIN program assessed the safety and efficacy of new anticoagulants in the treatment of deep vein thrombosis (DVT) and pulmonary embolism (PE) and in long-term thromboprophylaxis. The EINSTEIN-DVT study (clinicaltrials.gov NCT00440193) found that rivaroxaban $15 \mathrm{mg}$ twice daily for 21 days followed by $20 \mathrm{mg}$ once daily was effective in the reduction of symptomatic recurrent venous thromboembolism after 6 months of treatment, in addition to the standard treatment regimen including parenterally administered enoxaparin for 5 days followed by a VKA with a target international normalized ratio (INR) of 2.5. Major and clinically relevant non-major bleeding rates were similar between the two treatment groups (Table 3) (24,30). Results from the recently published EINSTEIN-PE study (clinicaltrials.gov NCT00439777) were similar, with rivaroxaban non-inferiority to standard therapy, at the same regimen, but in the treatment of PE. Major or clinically relevant non-major bleeding composite rates were also similar between the two treatment groups, but major bleeding rates alone, which were defined as secondary outcome, were found significantly inferior for rivaroxaban (31). 
Patients receiving initial antithrombotic therapy for DVT or PE were enrolled in the EINSTEINExtension study (clinicaltrials.gov NCT00439725), the results of which showed that rivaroxaban could be used for the long-term secondary prevention of VTE. Nevertheless, the risk of bleeding during long-term anticoagulant therapy should be evaluated carefully. Indeed, this study showed that after 6-12 months of treatment, rivaroxaban at a dose of $20 \mathrm{mg}$ once daily significantly reduced the risk of recurrent VTE at the cost of a moderate increase in clinically relevant non-major bleeding (Table 3) $(24,30,32)$.

Following a pivotal ROCKET AF study (clinicaltrials.gov NCT00403767) rivaroxaban has recently obtained marketing authorisation for the prevention of stroke and systemic embolism in patients with non-valvular atrial fibrillation (AF) and with one or more risk factor(s), such as congestive heart failure, hypertension, age $\geq 75$ years, diabetes mellitus, previous stroke or transient ischaemic attack. According to guidelines, VKAs are the reference oral anticoagulant therapy for stroke prevention in $\mathrm{AF}$ in patients with high risk of stroke, while acetylsalicylic acid is prescribed as first-line therapy in patients with low risk of stroke $(33,34)$. For this reason, rivaroxaban was compared to adjusted-dose warfarin (INR of prothrombin times ranging between 2.0 and 3.0) and only the noninferiority of rivaroxaban was established in the ROCKET AF study (Table 4). Major bleeding rates were similar between the two treatment groups, with fewer intracranial haemorrhages $(0.5 \%$ vs. $0.74 \% \mathrm{p}=0.02)$ and fatal bleeding $(0.2 \%$ versus $0.5 \%, \mathrm{p}=0.003)$ in the rivaroxaban group $(24,35)$. As a result, rivaroxaban can be prescribed as a first-line or second-line therapy (in cases of poorly-controlled INR under VKAs) in patients with moderate-to-high risk of stroke, in accordance with the marketing authorisation (36).

The efficacy and safety of rivaroxaban compared to enoxaparin were investigated for thrombosis prevention in hospitalized medically ill patients in the MAGELLAN program (clinicaltrials.gov NCT00571649). Although this study was completed in 2010, the results have not yet been published. Rivaroxaban was also assessed for the prevention of cardiovascular events in patients with acute coronary syndrome (ACS), with the ATLAS 2 TIMI 51 program following the ATLAS ACS TIMI 46 dose-finding phase II study (Table 5) (37).

\section{Apixaban}

Apixaban $\quad$ (Eliquis ${ }^{\circledR}$, Bristol-Myers Squibb / Pfizer) is the second advanced direct FXa inhibitor. The risk-benefit balance for apixaban was evaluated in two pivotal (non-inferiority) phase III studies on VTE prevention after major orthopaedic surgery in patients undergoing total knee replacement (ADVANCE-2) or total hip replacement (ADVANCE-3). Results from the ADVANCE program led to marketing authorisation in 2011. In both studies, apixaban at a dose of $2.5 \mathrm{mg}$ twice daily showed superior efficacy compared to enoxaparin in reduction of thromboembolic events after major orthopaedic surgery without increased risk of bleeding. It appears to have the same type of drug interactions as rivaroxaban, namely with inhibitors and inducers of CYP3A4 and with P-glycoprotein. Apixaban is contraindicated in patients with hepatic impairment and should be used with caution in patients with severe renal impairment $(38,39)$.

Apixaban is currently under evaluation for VTE prevention in patients hospitalized for an acute medical illness by the ADOPT phase III study (clinicaltrials.gov NCT00457002) and for VTE prevention in cancer patients by the ADVOCATE phase II study (clinicaltrials.gov NCT00320255).

Following the BOTTICELLI DVT doseranging study, a treatment regimen $(10 \mathrm{mg}$ apixaban twice daily for 7 days followed by $5 \mathrm{mg}$ twice daily) was selected for investigation in phase III studies (40). The AMPLIFY study (clinicaltrials.gov NCT00643201), investigating apixaban for the treatment of VTE at a higher dose for the first 7 days, as with rivaroxaban, compared to conventional therapy (LMWH followed by VKA), is underway. In the AMPLIFY-EXTENSION study (clinicaltrials.gov NCT00633893), apixaban $2.5 \mathrm{mg}$ or $5 \mathrm{mg}$ twice daily is compared to placebo for the secondary prevention of VTE. Both dosages of apixaban were significantly superior to placebo on the primary efficacy endpoint, defined as the composite of symptomatic recurrent venous thromboembolism or death from any cause, without increasing the rate of major bleeding. Only $15 \%$ of patients in this study were older than 75 years of age, and less than $6 \%$ had a creatinine clearance below $50 \mathrm{ml} / \mathrm{min}$. Therefore, for such patients, the authors conclude that more data are needed to clarify the benefit-to-risk profile of apixaban. (41)(Table 3). 
The ARISTOTLE program found that apixaban $5 \mathrm{mg}$ twice daily (or $2.5 \mathrm{mg}$ twice daily in selected patients) was non-inferior and even superior to warfarin in the prevention of stroke and systemic embolism in patients with nonvalvular $\mathrm{AF}$ and at least one risk factor for stroke (age > 75 years; previous stroke, transient ischaemic attack or systemic embolism; symptomatic heart failure or left ventricular ejection fraction < 40\%; diabetes mellitus; hypertension). Lower rates of bleeding and mortality were reported (Table 4). Indeed, the new anticoagulant reduces the risk of stroke or systemic embolism by $21 \%$, major bleeding by $31 \%$, and death by $11 \%$ compared to warfarin. Apixaban would prevent a haemorrhagic stroke in 4 patients per 1000 and an ischaemic or unknown type of stroke in 2 patients per 1000 (42).

In the ongoing AVERROES study (clinicaltrials.gov NCT00496769), apixaban $5 \mathrm{mg}$ twice a day (or $2.5 \mathrm{mg}$ twice daily in selected patients) seems promising for the prevention of stroke and systemic embolism in $\mathrm{AF}$ and demonstrates superior efficacy compared to acetylsalicylic acid (81-324 mg once daily). Indeed, apixaban substantially reduces risk of stroke or systemic embolism with no significant increase in major bleeding rates (Table 4). It presents fewer serious side effects and lower rates of discontinuation of medication compared with aspirin. Treating 1000 patients with apixaban rather than with aspirin for one year would prevent 21 strokes or systemic emboli, 9 deaths and 33 hospitalizations for cardiovascular causes at the cost of 2 major haemorrhages (43).

The APPRAISE-2 phase III trial evaluating the clinical benefit of apixaban for the secondary prevention of ACS was terminated prematurely at the recommendation of an independent monitoring and follow-up committee, because a significant increase in bleeding without a significant reduction in recurrent ischaemic events was reported in the apixaban group taken in combination with aspirin alone or with aspirin and clopidogrel compared to placebo (Table 5) (44).

The promising results from the AMPLIFY, ARISTOTLE and AVERROES programs could lead to indications for apixaban being extended in the coming years.

\section{Drugs currently in Clinical Development}

\section{Betrixaban}

Betrixaban (PRT 054021, Portola Pharmaceuticals) at doses of $15 \mathrm{mg}$ and $40 \mathrm{mg}$ twice daily showed an effective antithrombotic action and was well tolerated by patients during the EXPERT phase II study ongoing in the US and Canada for the prevention of VTE after orthopaedic surgery for total knee replacement (Table 6) (45). The efficacy and safety of this new anticoagulant have not yet been evaluated in phase III trials.

The results of the EXPLORE-Xa doseranging study (clinicaltrials.gov NCT00742859) investigating betrixaban for stroke prevention in patients with non-valvular AF are not yet available (Table 4).

\section{Edoxaban}

Edoxaban (DU-176b, Daiichi Sankyo), another oral direct factor Xa inhibitor, is currently under investigation for the prevention and treatment of VTE and for the prevention of systemic thromboembolism in AF.

The effectiveness of edoxaban as thromboprophylaxis for major orthopaedic surgery has been established in phase III studies (Table 6): for total knee replacement (STARS E3, clinicaltrials.gov NCT01181102), total hip replacement (J-STARS 5, clinicaltrials.gov NCT01181167) and hip fracture surgery (JSTARS 4 clinicaltrials.gov NCT01181141). Edoxaban at a dose of $30 \mathrm{mg}$ once daily was compared to enoxaparin $20 \mathrm{mg}$ twice daily and showed a significant reduction in venous thromboembolic events with no difference in major bleeding rates between treatment groups (46).

The HOKUSAI-VTE study (clinicaltrials.gov NCT00986154) is designed to investigate the efficacy and safety of edoxaban for the initial treatment of VTE. There is no specific dose study, therefore it is not possible to speculate on a higher dosage during the first days of treatment followed by a subsequent dosage reduction, as for rivaroxaban and apixaban. In the phase III study, edoxaban $60 \mathrm{mg}$ once daily is administered after initial parenteral anticoagulant therapy and this is compared to initial parenteral treatment followed by VKA (Table 3) (14).

The ENGAGE-AFTIMI-48 phase III study (clinicaltrials.gov NCT00781391) (47) is designed to compare edoxaban with warfarin for the prevention of thromboembolism in patients with AF. This study follows the dose-finding study (clinicaltrials.gov NCT00504556) (48), in which edoxaban $30 \mathrm{mg}$ or $60 \mathrm{mg}$ once daily showed a favorable side-effect profile in terms of efficacy and safety (Table 4). 


\section{Darexaban}

A number of phase II and III studies (clinicaltrials.gov NCT00353678, NCT00913120, NCT00902928) investigate darexaban (YM150, Astellas Pharma) in VTE prevention after hip arthroplasty (49-51) and evaluate the superiority of the new anticoagulant over enoxaparin (PEARL-1, clinicaltrials.gov NCT00408239), warfarin (PEARL, clinicaltrials.gov NCT00595426) and placebo (clinicaltrials.gov NCT00917254) in thromboprophylaxis after knee arthroplasty (Table 6).

Darexaban is also evaluated for the treatment of DVT and PE (clinicaltrials.gov NCT00937820) (Table 3), for the prevention of VTE in hospitalized medically ill patients (clinicaltrials.gov NCT01028950), after a hip fracture (clinicaltrials.gov NCT00937911) and after major abdominal surgery (clinicaltrials.gov NCT00942435).

Two phase II studies were designed to investigate an antithrombotic effect of the new drug in stroke prevention in patients with $\mathrm{AF}$ (clinicaltrials.gov NCT00448214 and OPAL-2, clinicaltrials.gov NCT00938730) (Table 4). Results were only published as abstracts $(52,53)$.

The RUBY-1 study (clinicaltrials.gov NCT00994292) evaluated darexaban in combination with dual antiplatelet therapy for the secondary prevention of ischemic vascular events after ACS. It found a two- to four-fold increase in major and clinically relevant non-major bleeding, with no significant increase in efficacy compared to placebo (Table 5). On the other hand, darexaban was well tolerated, with no signs of hepatotoxicity. A large phase III trial is required to demonstrate the potential of low-dose darexaban to prevent major cardiac events after ACS (54). However, considering these reserved results and intense competition for fruitful market of FXa inhibitors, Astellas has decided to discontinue development of darexaban for all indications.

\section{TAK-442}

Two dose-finding studies investigated the efficacy, safety and tolerability of TAK-442 (Takeda) in the prevention of VTE after total knee replacement and in the secondary prevention of ischemic vascular events in patients with ACS. In the first study (clinicaltrials.gov NCT00641732) recruitment was stopped early in the groups receiving TAK-442 at doses of $10 \mathrm{mg}$ or $20 \mathrm{mg}$ twice daily due to a high rate of DVT, EP or allcause mortality compared to control group. The efficacy and safety profiles of other doses were similar to enoxaparin (Table 6) (55). In the second study (clinicaltrials.gov NCT00677053), 8 dosage regimens of TAK-442 in combination with standard antiplatelet therapy were evaluated in terms of efficacy and safety versus placebo (Table 5 ). The results of this study are not yet available.

\section{LY517717}

In the phase II study (clinicaltrials.gov NCT00074828) LY517717 (Lilly), difumarate at doses of 100, 125 and $150 \mathrm{mg}$ demonstrated noninferior efficacy and similar bleeding rates compared to enoxaparin in the prevention of venous thromboembolic events after orthopaedic surgery of the lower limbs (hip or knee replacement) (Table 6) (56). No information on the future development of this drug is available.

\section{Eribaxaban}

Eribaxaban (PD 0348292, Pfizer) was assessed in a dose-ranging study (clinicaltrials.gov NCT00306254) for VTE prevention after total knee replacement. All doses were well tolerated. A dose-related increase in the incidence of bleeding events was not statistically significant (Table 6) (23). No information on future trials is available.

\section{Otamixaban}

Otamixaban (XRP0673, Sanofi-Aventis) is a novel intravenous short-acting direct FXa inhibitor that can be used in acute situations. Initially evaluated in non-urgent percutaneous coronary intervention (SEPIA-PCI clinicaltrials.gov NCT00133731), this drug showed promising results in terms of efficacy and safety (57).

In the SEPIA-ACS1 TIMI 42 phase II study, otamixaban was investigated in patients with nonST-segment elevation acute coronary syndromes and requiring revascularisation versus conventional anticoagulant (UFH) and antiplatelet (glycoprotein IIb/IIIa inhibitor) therapies (58). Administering eptifibatide before and during percutaneous coronary intervention in patients with unstable angina was found to significantly reduce the risk of death and myocardial infarction $(59,60)$.

The SEPIA-ACS1 TIMI 42 study recommended using intermediate doses of otamixaban in future studies as more appropriate: low doses were ineffective and high doses were shown to be dangerous. Treatment with otamixaban at doses of 0.105 and $0.140 \mathrm{mg} / \mathrm{kg} / \mathrm{h}$ was associated with a $40 \%$ reduction in myocardial infarction, ischaemic events and all- 
cause death without a significant increase in bleeding rates compared to UFH plus eptifibatide (Table 5) (61). A phase III study (clinicaltrials.gov NCT01076764) has begun recruitment.

Furthermore, the pharmacokinetic and pharmacodynamic profiles of otamixaban will be investigated in patients with mild, moderate or severe renal insufficiency (clinicaltrials.gov NCT01120314) and with mild or moderate hepatic insufficiency (clinicaltrials.gov NCT01126086).

\section{DISCUSSION}

Numerous direct and selective FXa inhibitors are currently in clinical development and emerging data suggest that new antithrombotic agents are safe and effective in preventing and treating VTE, stroke and systemic embolism in patients with $\mathrm{AF}$ or following orthopaedic surgery. Most of these drugs will probably replace VKAs, and sometimes even initial parenteral treatment with heparin.

The use of new anticoagulants offers advantages over conventional therapy: for example, orally administered FXa inhibitors can be taken at home; their rapid and predictable antithrombotic action does not require dose adjustment or routine coagulation monitoring; food does not modify blood concentration with these new agents and information about drug interactions is available. The most common side effects observed in clinical trials, other than haemorrhages, are anaemia, nausea, increase in transaminases and/or bilirubin. Concerning liver laboratory assessments, data from four studies conducted to compare the efficacy and safety of rivaroxaban (6131 subjects) with enoxaparin (6131 subjects) were included in a pooled analysis (62). $2.33 \%$ rivaroxaban subjects and $3.64 \%$ enoxaparin subjects experienced a peak of alanine transaminase superior of three times upper limit of normal (ULN) without elevation of total bilirubin superior of two times ULN. $0.16 \%$ of rivaroxaban and enoxaparin subjects experienced a peak of alanine transaminase superior of three times ULN with a peak of total bilirubin superior of two times ULN. Nevertheless, several potential limitations of these novel drugs should be considered in daily clinical practice:

- At present there is a lack of validated tests to monitor the antithrombotic action of these new drugs. Yet monitoring can be helpful in certain situations (e.g. urgently-needed surgery, suspected overdose, recurrence under treatment, doubts about drug administration) and adding intermediary endpoint measurement concerning bleeding risk in future clinical trials would be interesting.

- At the moment there is no specific antidote available to antagonize the effects of these drugs, so the treatment of major bleeding will be difficult when it occurs, or in emergency interventions. However, the search for an antidote is underway, and a recombinant factor Xa (PRT06445) presenting high affinity for direct and indirect FXa inhibitors was recently proposed as a potential antidote for new anticoagulants $(63,64)$.

- A number of new agents will become available over a relatively short time, without comparative studies. Pharmaceutical companies only provide the results of indirect comparisons of the new anticoagulants (rivaroxaban, apixaban, dabigatran).

- New antithrombotics are being investigated for some, but not all, indications. For example, no study about FXa inhibitors has involved patients with mechanical heart valves, although direct thrombin inhibitor dabigatran was investigated in this indication (65).

- The cost-effectiveness of new drugs compared with traditional anticoagulants has not yet been evaluated. VKAs are cheap and effective, although the cost and difficulty of routine coagulation monitoring should be taken into account.

- Potential long-term side effects are unknown, and this implies increased vigilance in clinical practice. It should be remembered that ximelagatran was withdrawn owing to serious hepatotoxicity. Moreover, although FXa inhibitors drug data mention a possible rise of amylase and lipase, pancreatic function has not been clearly studied.

- Clinical data are scare for patients with renal insufficiency; for this reason, UFH and VKAs will probably remain the reference drugs for these patients.

\section{CONCLUSION}

The short- and long-term therapeutic management of VTE will be considerably changed in the near future by the arrival on the market of new anticoagulants with targeted action on factor Xa, most of them orally active. Direct factor Xa inhibitors present a favorable safety and efficacy profile and offer an attractive option for the 
prevention and treatment of venous and arterial thromboembolism, in comparison to standard therapy with heparins and VKAs. At present, two drugs (Xarelto ${ }^{\mathbb{B}}$ and Eliquis ${ }^{\circledR}$ ) have obtained marketing authorisation for the prevention of venous thromboembolic events after scheduled orthopaedic surgery of the lower limbs, and rivaroxaban is also indicated for the prevention of stroke and systemic embolism in patients with non-valvular atrial fibrillation. However, it is early to talk of replacing standard antithrombotic therapy, given the current lack of objectivity and evidence. Further studies will be required before clinicians can be confident of the real conditions of use of these drugs, and of their ability to monitor coagulation and to manage adverse events associated with this new therapeutic class.

\section{CONFLICT OF INTEREST}

The authors have no conflict of interest to declare.

\section{KEYWORDS}

factor Xa inhibitors, new anticoagulants, rivaroxaban, apixaban, betrixaban, edoxaban, darexaban, TAK-442, LY517717, eribaxaban, otamixaban.

\section{REFERENCES}

1. Amin A, Stemkowski S, Lin J, et al. Thromboprophylaxis rates in US medical centers: success or failure? J Thromb Haemost, 2007; 5(8):1610-6.

2. Cohen AT, Agnelli G, Anderson FA, et al. Venous thromboembolism (VTE) in Europe. The number of VTE events and associated morbidity and mortality. Thromb Haemost, 2007; 98(4):756-64.

3. Société Française d'Anesthésie et de Réanimation (SFAR). Prévention de la maladie thromboembolique veineuse périopératoire et obstétricale Recommandations pour la pratique clinique 2005.

4. Bereznicki LR, Peterson GM. New antithrombotics for atrial fibrillation. Cardiovasc Ther, 2010; 28(5):278-86.

5. Go AS, Hylek EM, Phillips KA, et al. Prevalence of diagnosed atrial fibrillation in adults: national implications for rhythm management and stroke prevention: the AnTicoagulation and Risk Factors in Atrial Fibrillation (ATRIA) Study. JAMA, 2001; 285(18):2370-5.

6. Spyropoulos AC, Lin J. Direct medical costs of venous thromboembolism and subsequent hospital readmission rates: an administrative claims analysis from 30 managed care organizations. J Manag Care Pharm, 2007; 13(6):475-86.

7. Baser O. Prevalence and economic burden of venous thromboembolism after total hip arthroplasty or total knee arthroplast. Am J Manag Care, 2011; 17:S6-S8.

8. Geerts WH, Bergqvist D, Pineo GF, et al. Prevention of venous thromboembolism: American College of Chest Physicians EvidenceBased Clinical Practice Guidelines (8th Edition). Chest, 2008; 133(6 Suppl):381S-453S.

9. Kearon C, Kahn SR, Agnelli G, et al. Antithrombotic therapy for venous thromboembolic disease: American College of Chest Physicians Evidence-Based Clinical Practice Guidelines (8th Edition). Chest, 2008; 133(6 Suppl):454S-545S.

10. Agence française de sécurité sanitaire des produits de santé (Afssaps). Prévention et traitement de la maladie thrombo-embolique veineuse en médecine. Recommandations de bonne pratique 2009.

11. Hirsh J, Bauer KA, Donati MB, et al. Parenteral anticoagulants: American College of Chest Physicians Evidence-Based Clinical Practice Guidelines (8th Edition). Chest, 2008; $133(6$ Suppl):141S-159S.

12. Ansell J, Hirsh J, Hylek E, et al. Pharmacology and management of the vitamin $\mathrm{K}$ antagonists: American College of Chest Physicians EvidenceBased Clinical Practice Guidelines (8th Edition). Chest, 2008; 133(6 Suppl):160S-198S.

13. Weitz JI, Hirsh J, Samama MM, et al. New antithrombotic drugs: American College of Chest Physicians Evidence-Based Clinical Practice Guidelines (8th Edition). Chest, 2008; $133(6$ Suppl):234S-256S.

14. Bertoletti L, Mismetti P. Les nouveaux anticoagulants dans la maladie thromboembolique veineuse. Rev Mal Respir, 2011; 28(8):1008-16.

15. Lassen MR, Laux V. Emergence of new oral antithrombotics: a critical appraisal of their clinical potential. Vasc Health Risk Manag, 2008; 4(6):1373-86.

16. Steffel J, Braunwald E. Novel oral anticoagulants: focus on stroke prevention and treatment of venous thrombo-embolism. Eur Heart J, 2011; 32(16):1968-76.

17. Lip GYH, Larsen TB, Skjoth F, et al. Indirect comparisons of new oral anticoagulant drugs for efficacy and safety when used for stroke prevention in atrial fibrillation. J Am Coll Cardiol, 2012; 60(8):738-46.

18. Mantha S, Ansell F. An indirect comparison of dabigatran, rivaroxaban and apixaban for atrial fibrillation. Thromb Haemost, 2012; 108(3):47684.

19. Harenberg J, Marx S, Diener HC, et al. Comparison of efficacy and safety of dabigatran, rivaroxaban and apixaban in patients with atrial fibrillation using network meta-analysis. Int Angiol, 2012; 31(4):330-9.

20. Kansal AR, Sharma M, Bradley-Kennedy C, et al. Dabigatran versus rivaroxaban for the prevention of stroke and systemic embolism in atrial 
fibrillation in Canada. Thromb Haemost, 2012; 108(4):672-82.

21. Schneeweiss S, Gagne JJ, Patrick AR, et al. Comparative efficacy and safety of new oral anticoagulants in patients with atrial fibrillation. Circ Cardiovasc Qual Outcomes, 2012; 5(4):4806.

22. Tsiara S, Pappas K, Boutsis D, et al. New oral anticoagulants: should they replace heparins and warfarin? Hellenic J Cardiol, 2011; 52(1):52-67.

23. Perzborn E. Factor Xa inhibitors - new anticoagulants for secondary haemostasis. Hamostaseologie, 2009; 29(3):260-7.

24. European Medicines Agency. Summary of product characteristics - rivaroxaban (Xarelto ${ }^{\circledR}$ ) 2008. Available at http://www.ema.europa.eu.

25. Haute Autorité de Santé. Avis de la Commission de Transparence - Xarelto ${ }^{\circledR}$ 2009. Available at http://www.has-

sante.fr/portail/upload/docs/application/pdf/200902/xarelto_-_ct-6017.pdf.

26. Rosencher $\overline{\mathrm{N}}$, Arnaout L, Chabbouh $\mathrm{T}$, et al. Rivaroxaban $\left(\right.$ Xarelto $\left.^{\circledR}\right)$ : efficacité et tolérance. Ann Fr Anesth Reanim, 2008 Dec; 27(Suppl 3):S22-7.

27. Agnelli G, Gallus A, Goldhaber SZ, et al. Treatment of proximal deep-vein thrombosis with the oral direct factor $\mathrm{Xa}$ inhibitor rivaroxaban (BAY 59-7939): the ODIXa-DVT (Oral Direct Factor Xa Inhibitor BAY 59-7939 in Patients With Acute Symptomatic Deep-Vein Thrombosis) study. Circulation, 2007; 116(2):180-7.

28. Buller HR, Lensing AW, Prins MH, et al. A doseranging study evaluating once-daily oral administration of the factor $\mathrm{Xa}$ inhibitor rivaroxaban in the treatment of patients with acute symptomatic deep vein thrombosis: the EinsteinDVT Dose-Ranging Study. Blood, 2008; 112(6):2242-7.

29. Mismetti P, Laporte S. Rivaroxaban: données pharmaco-cliniques. Ann Fr Anesth Reanim, 2008; 27(Suppl 3):S16-21.

30. Bauersachs R, Berkowitz SD, Brenner B, et al. Oral rivaroxaban for symptomatic venous thromboembolism. N Engl J Med, 2010; 363(26):2499-510.

31. The EINSTEIN-PE Investigators, Oral Rivaroxaban for the treatment of symptomatic pulmonary embolism. N Engl J Med, 2012; 366:1287-97.

32. Romualdi E, Donadini MP, Ageno W. Oral rivaroxaban after symptomatic venous thromboembolism: the continued treatment study (EINSTEIN-extension study). Expert Rev Cardiovasc Ther, 2011; 9(7):841-4.

33. Singer DE, Albers GW, Dalen JE, et al. Antithrombotic therapy in atrial fibrillation, American College of Chest Physicians EvidenceBased Clinical Practice Guidelines (8th Edition). Chest, 2008; 133:546S-592S.

34. Fuster V, Rydén LE, Cannom DS, et al. 2011 ACCF/AHA/HRS focused updates incorporated into the ACC/AHA/ESC 2006 Guidelines for the management of patients with atrial fibrillation: A report of the American College of Cardiology Foundation/American Heart Association Task Force on Practice Guidelines developed in partnership with the European Society of Cardiology and in collaboration with the European Heart Rhythm Association and the Heart Rhythm Society. J Am Coll Cardiol, 2011; 57(11):e101-98.

35. Patel MR, Mahaffey KW, Garg J, et al. Rivaroxaban versus warfarin in non-valvular atrial fibrillation. N Engl J Med, 2011; 365(10):883-91.

36. Haute Autorité de Santé. Avis de la Commission de Transparence - Xarelto ${ }^{\circledR}$ 2012. Available at http://www.hassante.fr/portail/upload/docs/application/pdf/201204/xarelto_avc_14032012_avis_ct11771.pdf.

37. Mega JL, Braunwald E, Mohanavelu S, et al. Rivaroxaban versus placebo in patients with acute coronary syndromes (ATLAS ACS-TIMI 46): a randomised, double-blind, phase II trial. Lancet, 2009; 374(9683):29-38.

38. European Medicines Agency. Summary of product characteristics - apixaban (Eliquis ${ }^{\circledR}$ ) 2011. Available at http://www.ema.europa.eu.

39. Haute Autorité de Santé. Avis de la Commission de Transparence - Eliquis ${ }^{\circledR}$ 2012. Available at http://www.has-

sante.fr/portail/upload/docs/application/pdf/201202/eliquis_18012012_avis_ct11097.pdf.

40. Buller H, Deitchman D, Prins M, et al. Efficacy and safety of the oral direct factor $\mathrm{Xa}$ inhibitor apixaban for symptomatic deep vein thrombosis. The Botticelli DVT dose-ranging study. J Thromb Haemost, 2008; 6(8):1313-8.

41. Agnelli G, Buller HR, Cohen A, et al. Apixaban for Extended Treatment of venous thromboembolism N Engl J Med, 2012; DOI: 10.1056/NEJMoa1207541.

42. Granger CB, Alexander JH, McMurray JJ, et al. Apixaban versus warfarin in patients with atrial fibrillation. N Engl J Med, 2011; 365(11):981-92.

43. Connolly SJ, Eikelboom JC. Apixaban in patients with atrial fibrillation. $\mathrm{N}$ Engl J Med, 2011; 364:806-17.

44. Alexander JH, Lopes RD, James $\mathrm{S}$, et al. Apixaban with antiplatelet therapy after acute coronary syndrome. N Engl J Med, 2011; 365:699-708.

45. Turpie AG, Bauer KA, Davidson BL, et al. A randomized evaluation of betrixaban, an oral factor $\mathrm{Xa}$ inhibitor, for prevention of thromboembolic events after total knee replacement (EXPERT). Thromb Haemost, 2009; 101(1):68-76.

46. Gras J. Edoxaban for the prevention of thromboembolic events after surgery. Drugs Today (Barc), 2011; 47(10):753-61.

47. Ruff CT, Giugliano RP, Antman EM, et al. Evaluation of the novel factor $\mathrm{Xa}$ inhibitor edoxaban compared with warfarin in patients with atrial fibrillation: design and rationale for the 
Effective aNticoaGulation with factor $\mathrm{xA}$ next GEneration in Atrial Fibrillation-Thrombolysis In Myocardial Infarction study 48 (ENGAGE AFTIMI 48). Am Heart J, 2010; 160(4):635-41.

48. Weitz JI, Connolly SJ, Patel I, et al. Randomised, parallel-group, multicentre, multinational phase 2 study comparing edoxaban, an oral factor $\mathrm{Xa}$ inhibitor, with warfarin for stroke prevention in patients with atrial fibrillation. Thromb Haemost, 2010; 104(3):633-41.

49. Eriksson BI, Turpie AG, Lassen MR, et al. A dose escalation study of YM150, an oral direct factor $\mathrm{Xa}$ inhibitor, in the prevention of venous thromboembolism in elective primary hip replacement surgery. J Thromb Haemost, 2007; 5(8):1660-5.

50. Fuji T, Nakamura M, Takeuchi M. Darexaban for the prevention of venous thromboembolism in Asian patients undergoing orthopedic surgery: results from 2 randomized, placebo-controlled, double-blind studies. Clin Appl Thromb Hemost. 2012; doi: 10.1177/1076029612457810.

51. Eriksson BI, Turpie AG, Lassen MR, et al. Prevention of venous thromboembolism with an oral factor Xa inhibitor, YM150, after total hip arthroplasty. A dose finding study (ONYX-2). J Thromb Haemost, 2010; 8:714-21.

52. Lip GYH, Halperin JL, Petersen P, Rodgers GM, Renfurm RW. Safety and tolerability of the oral Factor Xa inhibitor, YM150 versus warfarin in 1297 patients with non-valvular atrial fibrillation: a dose confirmation study (OPAL-2). (Abstract OTH-083) J Thromb Haemost, 2011;9(Suppl 2):748. 53.

53. Turpie AGG, Lip GYH, Minematsu K, Goto S, Renfurm RW, Wong KSL. Safety and tolerability of YM150 in subjects with non-valvular atrial fibrillation: a phase II study. (Abstract 1194) Eur Heart J, 2010;31(Abstr. Supp.):173.

54. Steg PG, Mehta SR, Jukema JW, et al. RUBY-1: a randomized, double-blind, placebo-controlled trial of the safety and tolerability of the novel oral factor Xa inhibitor darexaban (YM150) following acute coronary syndrome. Eur Heart J, 2011; 32:2541-2554.

55. Weitz JI, Cao C, Eriksson BI, et al. A dose-finding study with TAK-442, an oral factor Xa inhibitor, in patients undergoing elective total knee replacement surgery. Thromb Haemost, 2010; 104(6):1150-7.

56. Agnelli G, Haas S, Ginsberg JS, et al. A phase II study of the oral factor Xa inhibitor LY517717 for the prevention of venous thromboembolism after hip or knee replacement. J Thromb Haemost, 2007; 5(4):746-53.

57. Cohen M, Bhatt DL, Alexander JH, et al. Randomized, double-blind, dose-ranging study of otamixaban, a novel, parenteral, short-acting direct factor Xa inhibitor, in percutaneous coronary intervention: the SEPIA-PCI trial. Circulation, 2007; 115(20):2642-51.

58. Anderson JL, Adams CD, Antman EM, et al. ACC/AHA 2007 guidelines for the management of patients with unstable angina/non ST-elevation myocardial infarction: A report of the American College of Cardiology/American Heart Association Task Force on Practice Guidelines. Circulation, 2007; 116:e148-304.

59. Bassand JP, Hamm CW, Ardissino D, et al. Guidelines for the diagnosis and treatment of nonST-segment elevation acute coronary syndromes. The Task Force for the Diagnosis and Treatment of Non-ST-Segment Elevation Acute Coronary Syndromes of the European Society of Cardiology. Eur Heart J, 2007; 28:1598-660.

60. Hamm CW, Bassand JP, Agewall S, et al. ESC Guidelines for the management of acute coronary syndromes in patients presenting without persistent ST-segment elevation: The Task Force for the management of acute coronary syndromes (ACS) in patients presenting without persistent ST-segment elevation of the European Society of Cardiology (ESC). Eur Heart J, 2011; 32(23):2999-3054.

61. Sabatine MS, Antman ES, Widimsky P, et al. Otamixaban for the treatment of patients with nonST-elevation acute coronary syndromes (SEPIAACS1 TIMI 42): a randomised, double-blind, active-controlled, phase 2 trial. Lancet, 2009; 374:787-95.

62. Watkins PB, Desai M, Berkowitz SD, et al. evaluation of drug-induced serious hepatotoxicity (eDISH): application of this data organization approach to phase III clinical trials of rivaroxaban after total hip or knee replacement surgery. Drug Saf, 2011; 34(3): 243-52.

63. Ageno W, Gallus AS, Wittkowsky A, et al. Oral anticoagulant therapy: Antithrombotic therapy and prevention of thrombosis, American College of Chest Physicians Evidence-Based Clinical Practice Guidelines (9th Edition). Chest, 2012; 141(2 Suppl):e44S-88S.

64. Ruff CT, Giugliano RP. Novel Oral Antithrombotic Therapies for Patients With Atrial Fibrillation. The American Journal of Cardiology. Available at http://elsevierocme.com/wpcontent/uploads/2010/09/930009_Afib-AJCUpdate.pdf.

65. Van de Werf F, Brueckmann M, Connolly SJ, et al. A comparison of dabigatran etexilate with warfarin in patients with mechanical heart valves: THE Randomized, phase II study to evaluate the safety and pharmacokinetics of oral dabigatran etexilate in patients after heart valve replacement (RE-ALIGN). Am Heart J, 2012; 163(6):931-7. 


\begin{tabular}{|c|c|c|c|c|c|c|c|c|}
\hline Anticoagulant & Study / Design & $\begin{array}{l}\text { Number } \\
\text { of patients } \\
\text { / period }\end{array}$ & Regimen & Control & $\begin{array}{l}\text { Efficacy } \\
\text { endpoint }\end{array}$ & Results: Efficacy & Safety endpoint & Results: Safety \\
\hline \multirow[t]{3}{*}{ Rivaroxaban } & $\begin{array}{l}\text { EINSTEIN- DVT: phase III, } \\
\text { randomized, open-label, non- } \\
\text { inferiority }\end{array}$ & $\begin{array}{l}3449 / \\
3,6, \text { or } 12 \\
\text { months }\end{array}$ & $\begin{array}{l}15 \mathrm{mg} \text { bid for } 3 \\
\text { weeks followed } \\
\text { by } 20 \mathrm{mg} \text { od }\end{array}$ & $\begin{array}{l}\text { Enoxaparin for } 5 \\
\text { days followed by } \\
\text { VKA (INR 2-3) }\end{array}$ & $\begin{array}{l}\text { Symptomatic } \\
\text { recurrent VTE }\end{array}$ & $\begin{array}{l}2.1 \% \text { vs } 3.0 \% \\
\text { ( }<<0.0001 \text { for non- } \\
\text { inferiority) }\end{array}$ & $\begin{array}{l}\text { Major bleeding; clinically } \\
\text { relevant non-major bleeding }\end{array}$ & $\begin{array}{l}0.8 \% \text { vs } 1.2 \% \\
(\mathrm{p}=0.21) ; 7.3 \% \text { vs } \\
7.0 \%\end{array}$ \\
\hline & $\begin{array}{l}\text { EINSTEIN- Extension: phase } \\
\text { III, randomized, double-blind, } \\
\text { superiority }\end{array}$ & $\begin{array}{l}1197 / \\
6 \text { or } 12 \\
\text { months }\end{array}$ & $20 \mathrm{mg}$ od & Placebo & $\begin{array}{l}\text { Symptomatic } \\
\text { recurrent VTE }\end{array}$ & $\begin{array}{l}1.3 \% \text { vs } 7.1 \% \\
(p<0.0001 \text { for } \\
\text { superiority) }\end{array}$ & $\begin{array}{l}\text { Major bleeding; clinically } \\
\text { relevant non-major bleeding }\end{array}$ & $\begin{array}{l}0.7 \% \text { vs } 0 \% \\
(\mathrm{p}=0.11) ; 5.4 \% \text { vs } \\
1.2 \%\end{array}$ \\
\hline & $\begin{array}{l}\text { EINSTEIN-PE: phase III, } \\
\text { randomized, open-label, non- } \\
\text { inferiority }\end{array}$ & $\begin{array}{l}4833 / \\
3,6 \text { or } 12 \\
\text { months }\end{array}$ & $\begin{array}{l}15 \mathrm{mg} \text { bid for } 3 \\
\text { weeks followed } \\
\text { by } 20 \mathrm{mg} \text { od }\end{array}$ & $\begin{array}{l}\text { Enoxaparin for } 5 \\
\text { days followed by } \\
\text { VKA (INR 2-3) }\end{array}$ & $\begin{array}{l}\text { Symptomatic } \\
\text { recurrent VTE }\end{array}$ & $\begin{array}{l}2.1 \% \text { vs } 1.8 \% \\
(\mathrm{p}=0.003 \text { for non- } \\
\text { inferiority) }\end{array}$ & $\begin{array}{l}\text { Major bleeding; clinically } \\
\text { relevant non-major bleeding }\end{array}$ & $\begin{array}{l}1.1 \% \text { vs } 2.2 \% \\
(p=0.003)\end{array}$ \\
\hline \multirow[t]{2}{*}{ Apixaban } & $\begin{array}{l}\text { AMPLIFY: phase III, } \\
\text { randomized, double-blind, } \\
\text { non-inferiority }\end{array}$ & $\begin{array}{l}5400 / \\
6 \text { months }\end{array}$ & $\begin{array}{l}10 \mathrm{mg} \text { bid for } 7 \\
\text { days followed } \\
\text { by } 5 \mathrm{mg} \text { bid }\end{array}$ & $\begin{array}{l}\text { Enoxaparin } \\
\text { followed by VKA } \\
\text { (INR 2-3) }\end{array}$ & $\begin{array}{l}\text { Venous } \\
\text { thromboembolic } \\
\text { recurrence or } \\
\text { death }\end{array}$ & Underway & Bleeding & Underway \\
\hline & $\begin{array}{l}\text { AMPLIFY-EXT: phase III, } \\
\text { randomized, double-blind, } \\
\text { non-inferiority }\end{array}$ & $\begin{array}{l}316 / \\
12 \text { months }\end{array}$ & 5 or $2.5 \mathrm{mg}$ bid & Placebo & $\begin{array}{l}\text { Venous } \\
\text { thromboembolic } \\
\text { recurrence or } \\
\text { death }\end{array}$ & $\begin{array}{l}\text { 5mg: } 4.2 \% \text { vs } \\
11.6 \% \\
2.5 \mathrm{mg}: 3.8 \% \text { vs } \\
11.6 \%(\mathrm{p}<0.001)\end{array}$ & Major bleeding & $\begin{array}{l}\text { 5mg: } 0.1 \% \\
\text { 2.5mg: } 0.2 \% \\
\text { placebo: } 0.5 \%\end{array}$ \\
\hline Edoxaban (DU-176b) & $\begin{array}{l}\text { HOKUSAI-VTE: phase III, } \\
\text { randomized, double-blind, } \\
\text { non-inferiority }\end{array}$ & $\begin{array}{l}8250 / \\
12 \text { months }\end{array}$ & $\begin{array}{l}60 \mathrm{mg} \text { od }+ \\
\text { heparin }\end{array}$ & Heparin/VKA & $\begin{array}{l}\text { Symptomatic } \\
\text { recurrent VTE }\end{array}$ & Underway & Clinically relevant bleeding & Underway \\
\hline Darexaban (YM150) & $\begin{array}{l}\text { NCT00937820: phase III, } \\
\text { non-randomized, open-label }\end{array}$ & $\begin{array}{l}87 / \\
52 \text { weeks }\end{array}$ & & - & $\begin{array}{l}\text { Incidence of } \\
\text { DVT and PE }\end{array}$ & Underway & Incidence of bleeding event & Underway \\
\hline
\end{tabular}




\begin{tabular}{|c|c|c|c|c|c|c|c|c|}
\hline Anticoagulant & Study / Design & $\begin{array}{l}\text { Number of } \\
\text { patients / Period }\end{array}$ & Regimen & Control & Efficacy endpoint & Results: Efficacy & Safety endpoint & Results: Safety \\
\hline Rivaroxaban & $\begin{array}{l}\text { ROCKET AF / phase III, } \\
\text { randomized, double-blind, } \\
\text { non-inferiority }\end{array}$ & $\begin{array}{l}14264 / 32 \\
\text { months up to } 4 \\
\text { years }\end{array}$ & $\begin{array}{l}20 \mathrm{mg} \text { od }(15 \mathrm{mg} \text { od } \\
\text { in patients with } \\
\text { moderate renal } \\
\text { insufficiency) }\end{array}$ & Warfarin (INR 2-3) & $\begin{array}{l}\text { Composite of stroke } \\
\text { and non-central } \\
\text { nervous system } \\
\text { systemic embolism }\end{array}$ & $\begin{array}{l}1.7 \% / \text { year vs } \\
2.2 \% / \text { year } \\
\text { ( }<<0.001 \text { for non- } \\
\text { inferiority) }\end{array}$ & $\begin{array}{l}\text { Major and clinically } \\
\text { relevant non-major } \\
\text { bleeding events; } \\
\text { major bleeding }\end{array}$ & $\begin{array}{l}14.9 \% / \text { year vs } 14.5 \% / \text { year } \\
\text { ( }=0.44 \text { for superiority) } \\
3.6 \% / \text { year vs } 3.4 \% / \text { year } \\
(p=0.58)\end{array}$ \\
\hline \multirow[t]{2}{*}{ Apixaban } & $\begin{array}{l}\text { ARISTOTLE / phase III, } \\
\text { randomized, double-blind }\end{array}$ & $\begin{array}{l}18201 / 1.8 \\
\text { years on average }\end{array}$ & $\begin{array}{l}5 \mathrm{mg} \text { bid }(2.5 \mathrm{mg} \\
\text { bid in selected } \\
\text { patients })\end{array}$ & Warfarin (INR 2-3) & $\begin{array}{l}\text { Stroke or systemic } \\
\text { embolism; death } \\
\text { from any cause }\end{array}$ & $\begin{array}{l}1.27 \% / \text { year vs } \\
1.60 \% / \text { year } \\
(\mathrm{p}<0.001 \text { for non- } \\
\text { inferiority, } \\
\mathrm{p}=0.01 \text { for } \\
\text { superiority); } \\
3.52 \% / \text { year vs } \\
3.94 \% / \text { year } \\
(\mathrm{p}=0.047)\end{array}$ & Major bleeding & $\begin{array}{l}2.13 \% / \text { year vs } 3.09 \% / \text { year } \\
(\mathrm{p}<0.001)\end{array}$ \\
\hline & $\begin{array}{l}\text { AVERROES / phase III, } \\
\text { randomized, double-blind, } \\
\text { superiority }\end{array}$ & $\begin{array}{l}5599 / 1.1 \text { years } \\
\text { on average }\end{array}$ & $\begin{array}{l}5 \mathrm{mg} \text { bid }(2.5 \mathrm{mg} \\
\text { bid in selected } \\
\text { patients) }\end{array}$ & $\begin{array}{l}\text { Acetylsalicylic } \\
\text { acide }(81-324 \mathrm{mg} \\
\text { od) }\end{array}$ & $\begin{array}{l}\text { Stroke or systemic } \\
\text { embolism }\end{array}$ & $\begin{array}{l}1.6 \% / \text { year vs } \\
3.7 \% / \text { year } \\
(p<0.001)\end{array}$ & Major bleeding & $\begin{array}{l}1.4 \% / \text { year vs } 1.2 \% / \text { year } \\
(p=0.57)\end{array}$ \\
\hline Betrixaban & $\begin{array}{l}\text { EXPLORE-Xa / phase II, } \\
\text { randomized, double-blind }\end{array}$ & $508 / 3$ months & $\begin{array}{l}40 \mathrm{mg}, 60 \mathrm{mg} \text { or } \\
80 \mathrm{mg} \text { od }\end{array}$ & $\begin{array}{l}\text { Open-label warfarin } \\
\text { (INR 2-3) }\end{array}$ & & Underway & $\begin{array}{l}\text { Major and clinically } \\
\text { relevant non-major } \\
\text { bleeding events }\end{array}$ & Underway \\
\hline \multirow[t]{2}{*}{ Edoxaban } & $\begin{array}{l}\text { NCT00504556/ phase II, } \\
\text { randomized, double-blind }\end{array}$ & $\begin{array}{l}1146 / 3 \\
\text { months }\end{array}$ & $\begin{array}{l}30 \mathrm{mg} \text { and } 60 \mathrm{mg} \\
\text { od, } 30 \mathrm{mg} \text { and } \\
60 \mathrm{mg} \text { bid }\end{array}$ & $\begin{array}{l}\text { Open-label warfarin } \\
\text { (INR 2-3) }\end{array}$ & & Underway & $\begin{array}{l}\text { Major and clinically } \\
\text { relevant non-major } \\
\text { bleeding events }\end{array}$ & $\begin{array}{l}10.6 \%, 7.8 \%, 3.8 \%, 3.0 \% \\
\text { for } 60 \mathrm{mg} \text { bid, } 30 \mathrm{mg} \text { bid, } \\
60 \mathrm{mg} \text { od, } 30 \mathrm{mg} \text { od, } \\
\text { respectively, vs } 3.2 \%\end{array}$ \\
\hline & $\begin{array}{l}\text { ENGAGE-AF TIMI-48 / } \\
\text { phase III, randomized, } \\
\text { double-blind, non-inferiority }\end{array}$ & $\begin{array}{l}20500 / 24 \\
\text { months }\end{array}$ & $\begin{array}{l}30 \mathrm{mg} \text { and } 60 \mathrm{mg} \\
\text { od }\end{array}$ & Warfarin (INR 2-3) & $\begin{array}{l}\text { Stroke and systemic } \\
\text { embolism }\end{array}$ & Underway & Major bleeding & Underway \\
\hline \multirow[t]{2}{*}{$\begin{array}{l}\text { Darexaban } \\
\text { (YM-150) }\end{array}$} & $\begin{array}{l}\text { NCT00448214 / phase II, } \\
\text { randomized, double-blind }\end{array}$ & 448 / 16 weeks & $\begin{array}{l}30 \mathrm{mg}, 60 \mathrm{mg} \text {, } \\
120 \mathrm{mg} \text { and } 240 \mathrm{mg} \\
\text { od }\end{array}$ & $\begin{array}{l}\text { Open-label warfarin } \\
\text { (INR 2-3) }\end{array}$ & $\begin{array}{l}\text { Stroke and systemic } \\
\text { embolism }\end{array}$ & $\begin{array}{l}\text { No } \\
\text { thromboembolic } \\
\text { strokes reported }\end{array}$ & $\begin{array}{l}\text { Major and clinically } \\
\text { relevant non-major } \\
\text { bleeding events }\end{array}$ & $\begin{array}{l}2.2 \%, 2.2 \%, 3.2 \% \text { and } \\
16.7 \% \text { for } 30 \mathrm{mg} \text { od, } 60 \mathrm{mg} \\
\text { od, } 120 \mathrm{mg} \text { od, } 240 \mathrm{mg} \text { od vs } \\
2.1 \%\end{array}$ \\
\hline & $\begin{array}{l}\text { OPAL-2 / phase II, } \\
\text { randomized, double-blind }\end{array}$ & $\begin{array}{l}1280 / 16 \\
\text { months }\end{array}$ & 6 doses & Warfarin (INR 2-3) & $\begin{array}{l}\text { Stroke, systemic } \\
\text { embolism, all deaths }\end{array}$ & Not detailed & $\begin{array}{l}\text { Major and clinically } \\
\text { relevant non-major } \\
\text { bleeding events }\end{array}$ & Not detailed \\
\hline
\end{tabular}




\begin{tabular}{|c|c|c|c|c|c|c|c|c|}
\hline Anticoagulant & Study / Design & $\begin{array}{l}\text { Number of patients } \\
\text { / Period }\end{array}$ & Regimen & Control & Efficacy endpoint & Results : Efficacy & Safety endpoint & Results : Safety \\
\hline Rivaroxaban & $\begin{array}{l}\text { ATLAS ACS } 2 \\
\text { TIMI } 46 \text { / phase } \\
\text { II, randomized, } \\
\text { double-blind }\end{array}$ & 3491 / 6 months & $\begin{array}{l}5 \mathrm{mg}, 10 \mathrm{mg}, 15 \mathrm{mg} \text {, } \\
20 \mathrm{mg} \text { od or bid }+ \\
\text { aspirin or aspirin } \\
\text { /thienopyridine }\end{array}$ & Placebo & $\begin{array}{l}\text { Composite of death, } \\
\text { MI, stroke, or severe } \\
\text { recurrent ischaemia } \\
\text { requiring } \\
\text { revascularisation }\end{array}$ & $\begin{array}{l}8.7 \%, 5.3 \%, 5.2 \%, 5.3 \% \text {, } \\
4.4 \%, 6.5 \% \text { for } 5 \mathrm{mg}, 10 \mathrm{mg} \text {, } \\
20 \mathrm{mg} \text { od, respectively, vs } \\
7.0 \% ; 5 \mathrm{mg}, 10 \mathrm{mg}, 20 \mathrm{mg} \text { bid, } \\
\text { respectively, vs } 7.0 \% ; 6.3 \% \\
\text { and } 6.5 \%(15 \mathrm{mg} \text { od and bid) } \\
\text { vs } 5.1 \%\end{array}$ & $\begin{array}{l}\text { Clinically significant } \\
\text { bleeding according to the } \\
\text { TIMI definition }\end{array}$ & $\begin{array}{l}7.4 \%, 10.8 \%, 16.0 \% \text { for } \\
5 \mathrm{mg}, 10 \mathrm{mg}, 20 \mathrm{mg} \text { od, } \\
\text { respectively, vs } 3.3 \% \text {; } \\
4.8 \%, 11.0 \%, 14.6 \% \text { for } \\
5 \mathrm{mg}, 10 \mathrm{mg}, 20 \mathrm{mg} \text { bid, } \\
\text { respectively, vs } 3.3 \% \text {; } \\
13.1 \% \text { and } 12.3 \%(15 \mathrm{mg} \mathrm{od} \\
\text { and bid) vs } 3.8 \%\end{array}$ \\
\hline Apixaban & $\begin{array}{l}\text { APPRAISE-2 / } \\
\text { phase III, } \\
\text { randomized, } \\
\text { double-blind, } \\
\text { superiority }\end{array}$ & $\begin{array}{l}7392 \text { / terminated } \\
\text { prematurely }\end{array}$ & $5 \mathrm{mg}$ bid & Placebo & $\begin{array}{l}\text { Composite of } \\
\text { cardiovascular death, } \\
\text { MI, or ischemic } \\
\text { stroke }\end{array}$ & $7.5 \%$ vs $7.9 \%(p=0.51)$ & $\begin{array}{l}\text { Major bleeding } \\
\text { according to the TIMI } \\
\text { definition }\end{array}$ & $1.3 \%$ vs $0.5 \%(\mathrm{p}=0.001)$ \\
\hline $\begin{array}{l}\text { Darexaban } \\
\text { (YM150) }\end{array}$ & $\begin{array}{l}\text { RUBY-1 / phase } \\
\text { II, randomized, } \\
\text { double-blind }\end{array}$ & 1279 / 26 weeks & $\begin{array}{l}5 \mathrm{mg} \text { bid, } 10 \mathrm{mg} \text { od, } \\
15 \mathrm{mg} \text { bid, } 30 \mathrm{mg} \\
\text { od, } 30 \mathrm{mg} \text { bid or } \\
60 \mathrm{mg} \text { od }+ \text { dual } \\
\text { antiplatelet therapy }\end{array}$ & Placebo & $\begin{array}{l}\text { Composite of all- } \\
\text { cause mortality, non- } \\
\text { fatal MI, non-fatal } \\
\text { stroke, severe } \\
\text { recurrent ischaemia }\end{array}$ & $\begin{array}{l}3.8 \%, 3.8 \%, 6.3 \%, 6.4 \% \text {, } \\
5.9 \%, 7.8 \% \text { for } 5 \mathrm{mg} \text { bid, } \\
10 \mathrm{mg} \text { od, } 15 \mathrm{mg} \text { bid, } 30 \mathrm{mg} \\
\text { od, } 30 \mathrm{mg} \text { bid, } 60 \mathrm{mg} \text { od, } \\
\text { respectively, vs } 4.4 \%\end{array}$ & $\begin{array}{l}\text { Major and clinically } \\
\text { relevant non-major } \\
\text { bleeding events }\end{array}$ & $\begin{array}{l}5.7 \%, 5.0 \%, 6.3 \%, 5.1 \% \text {, } \\
9.8 \%, 6.5 \% \text { for } 5 \mathrm{mg} \text { bid, } \\
10 \mathrm{mg} \text { od, } 15 \mathrm{mg} \text { bid, } 30 \mathrm{mg} \\
\text { od, } 30 \mathrm{mg} \text { bid, } 60 \mathrm{mg} \text { od, } \\
\text { respectively, vs } 2.8 \%\end{array}$ \\
\hline TAK-442 & $\begin{array}{l}\text { NCT00677053 / } \\
\text { phase II, } \\
\text { randomized, } \\
\text { double-blind }\end{array}$ & 2753 / 24 weeks & $\begin{array}{l}40,80 \text { and } 160 \mathrm{mg} \\
\text { od, } 10,20,40,80 \\
\text { and } 120 \mathrm{mg} \text { bid }+ \\
\text { antiplatelet therapy }\end{array}$ & $\begin{array}{l}\text { Placebo }+ \\
\text { antiplatelet } \\
\text { therapy }\end{array}$ & $\begin{array}{l}\text { Composite of } \\
\text { cardiovascular } \\
\text { mortality, non-fatal } \\
\text { MI, non-fatal stroke } \\
\text { or myocardial } \\
\text { ischaemia requiring } \\
\text { hospitalization }\end{array}$ & Underway & $\begin{array}{l}\text { Major bleeding events } \\
\text { defined by the } \\
\text { thrombolysis in MI scale }\end{array}$ & Underway \\
\hline \multirow[t]{2}{*}{$\begin{array}{l}\text { Otamixaban } \\
\text { (XRP0673) }\end{array}$} & $\begin{array}{l}\text { SEPIA- } \\
\text { ACS1TIMI 42/ } \\
\text { phase II, } \\
\text { randomized, } \\
\text { double-blind }\end{array}$ & 3241 / 7-30 days & \multirow[t]{2}{*}{$\begin{array}{l}0.08 \mathrm{mg} / \mathrm{kg} \text { bolus } \\
\text { followed by } \\
\text { infusions of } 0.035 \text {, } \\
0.070,0.105 \text {, } \\
0.140 \text { or } \\
0.175 \mathrm{mg} / \mathrm{kg} / \mathrm{h}\end{array}$} & $\begin{array}{l}\text { UFH }+ \\
\text { eptifibatide }\end{array}$ & $\begin{array}{l}\text { Composite of all- } \\
\text { cause death, MI, } \\
\text { urgent } \\
\text { revascularisation or } \\
\text { bailout glycoprotein } \\
\text { IIb/IIIa inhibitor use } \\
\text { up to } 7 \text { days }\end{array}$ & $\begin{array}{l}7.2 \%, 4.6 \%, 3.8 \%, 3.6 \% \text { et } \\
4.3 \% \text { for } 0.035,0.070 \\
0.105,0.140 \text { and } \\
0.175 \mathrm{mg} / \mathrm{kg} / \mathrm{h} \text {, respectively, } \\
\text { vs } 6.2 \%\end{array}$ & $\begin{array}{l}\text { TIMI major or minor } \\
\text { bleeding not related to } \\
\text { coronary-artery bypass } \\
\text { grafting up to } 7 \text { days }\end{array}$ & $\begin{array}{l}1.6 \%, 1.6 \%, 3.1 \%, 3.4 \% \\
\text { and } 5.4 \% \text { for } 0.035,0.070 \text {, } \\
0.105,0.140 \text { and } \\
0.175 \mathrm{mg} / \mathrm{kg} / \mathrm{h} \text {, respectively, } \\
\text { vs } 2.7 \%\end{array}$ \\
\hline & $\begin{array}{l}\text { NCT01076764 / } \\
\text { phase III, } \\
\text { randomized, } \\
\text { double-blind, } \\
\text { superiority }\end{array}$ & $30-180$ days & & $\begin{array}{l}\text { UFH }+ \\
\text { eptifibatide }\end{array}$ & $\begin{array}{l}\text { Composite of all- } \\
\text { cause death and MI }\end{array}$ & Underway & $\begin{array}{l}\text { TIMI major and minor } \\
\text { bleeding }\end{array}$ & Underway \\
\hline
\end{tabular}




\begin{tabular}{|c|c|c|c|c|c|c|c|c|}
\hline Anticoagulant & Study / Design & $\begin{array}{l}\text { Number of } \\
\text { patients / Period }\end{array}$ & Regimen & Control & Efficacy endpoint & Results : Efficacy & Safety endpoint & Results : Safety \\
\hline Betrixaban & $\begin{array}{l}\text { EXPERT / phase II, } \\
\text { randomized, open-label, } \\
\text { TKR }\end{array}$ & $215 / 10-14$ days & $\begin{array}{l}15 \mathrm{mg} \text { bid or } 40 \mathrm{mg} \\
\text { bid }\end{array}$ & Enoxaparin 30mg & Incidence of VTE & $\begin{array}{l}20 \%(15 \mathrm{mg}), 15 \% \\
(40 \mathrm{mg}) \text { vs } 10 \%\end{array}$ & $\begin{array}{l}\text { Major or } \\
\text { clinically } \\
\text { significant non- } \\
\text { major bleeding } \\
\text { events }\end{array}$ & $\begin{array}{l}\text { major bleeding: } 0 \% \text { vs } \\
2.3 \% \text {; non-major } \\
\text { bleeding: } 0 \%(15 \mathrm{mg}) \\
\text { and } 2.4 \%(40 \mathrm{mg}) \text { vs } \\
4.6 \%\end{array}$ \\
\hline \multirow[t]{3}{*}{ Edoxaban } & $\begin{array}{l}\text { STARS E-3 / phase III, } \\
\text { randomized, double- } \\
\text { blind, TKR }\end{array}$ & 716 / 2 weeks & $30 \mathrm{mg}$ od & $\begin{array}{l}\text { Enoxaparin 20mg } \\
\text { bid }\end{array}$ & Incidence of VTE & Underway & Bleeding events & Underway \\
\hline & $\begin{array}{l}\text { STARS J-5 / phase III, } \\
\text { randomized, double- } \\
\text { blind, THR }\end{array}$ & $610 / 2$ weeks & $30 \mathrm{mg}$ od & $\begin{array}{l}\text { Enoxaparin 20mg } \\
\text { bid }\end{array}$ & Incidence of VTE & Underway & Bleeding events & Underway \\
\hline & $\begin{array}{l}\text { STARS J-4 / phase III, } \\
\text { randomized, open-label, } \\
\text { hip fracture surgery }\end{array}$ & $92 / 2$ weeks & $30 \mathrm{mg}$ od & $\begin{array}{l}\text { Enoxaparin 20mg } \\
\text { bid }\end{array}$ & Incidence of VTE & Underway & Bleeding events & Underway \\
\hline \multirow[t]{5}{*}{$\begin{array}{l}\text { Darexaban } \\
\text { (YM150) }\end{array}$} & $\begin{array}{l}\text { phase II, dose } \\
\text { escalation, randomized, } \\
\text { double-blind, THR }\end{array}$ & 174 / 7-10 days & $3,10,30$ or $60 \mathrm{mg}$ od & Enoxaparin 40mg & Incidence of VTE & $\begin{array}{l}51.9 \%, 38.7 \%, 22.6 \% \\
\text { and } 18.5 \% \text { for } 3,10,30 \\
\text { and } 60 \mathrm{mg} \text { od, } \\
\text { respectively, vs } 38.7 \%\end{array}$ & $\begin{array}{l}\text { Major or } \\
\text { clinically relevant } \\
\text { non-major } \\
\text { bleeding events }\end{array}$ & $\begin{array}{l}\text { No major and } 3 \\
\text { clinically relevant non- } \\
\text { major bleeding ( } 2.9 \% \text {, } \\
5.7 \%, 0 \% \text { and } 0 \% \text { in the } \\
3,10,30 \text { and } 60 \mathrm{mg} \text {, } \\
\text { respectively) vs } 0 \text { event }\end{array}$ \\
\hline & $\begin{array}{l}\text { ONYX-2 / phase II, } \\
\text { dose finding, } \\
\text { randomized, double- } \\
\text { blind, THR }\end{array}$ & 1017 / 5 weeks & $\begin{array}{l}5,10,30,60 \text { or } \\
120 \mathrm{mg} \text { od }\end{array}$ & Enoxaparin 40mg & $\begin{array}{l}\text { Incidence of VTE } \\
\text { up to } 9 \text { days after } \\
\text { surgery }\end{array}$ & $\begin{array}{l}27.4 \%, 31.7 \%, 19.3 \% \text {, } \\
13.3 \% \text { or } 14.5 \% \text { for } 5, \\
10,30,60 \text { and } 120 \mathrm{mg}, \\
\text { respectively, vs } 18.9 \%\end{array}$ & $\begin{array}{l}\text { Major bleeding } \\
\text { up to } 9 \text { days after } \\
\text { surgery }\end{array}$ & $\begin{array}{l}1 \text { event (60mg) vs } 1 \\
\text { event }\end{array}$ \\
\hline & $\begin{array}{l}\text { NCT00913120 / phase } \\
\text { II and III, randomized, } \\
\text { double-blind, THR }\end{array}$ & $610 / 2$ weeks & 15 and $30 \mathrm{mg}$ bid & $\begin{array}{l}\text { Enoxaparin and } \\
\text { placebo }\end{array}$ & Incidence of VTE & $\begin{array}{l}2.9 \%, 5.2 \% \text { for } 15 \text { and } \\
30 \mathrm{mg} \text { vs } 17.1 \% \text { placebo } \\
\text { and } 2.4 \% \text { enoxaparin }\end{array}$ & Bleeding events & $\begin{array}{l}9.5 \%, 10.3 \% \text { for } 15 \text { and } \\
30 \mathrm{mg} \text { vs } 7.4 \% \text { placebo } \\
\text { and } 11.7 \% \text { enoxaparin }\end{array}$ \\
\hline & $\begin{array}{l}\text { ONYX-3 / phase II and } \\
\text { III, randomized, } \\
\text { double-blind, THR }\end{array}$ & 1992 & 4 doses & Enoxaparin 40mg & $\begin{array}{l}\text { Incidence of VTE } \\
\text { and death from all } \\
\text { causes }\end{array}$ & Underway & Bleeding events & Underway \\
\hline & $\begin{array}{l}\text { PEARL-1 / phase II, } \\
\text { dose escalation, } \\
\text { randomized, open-label, } \\
\text { TKR }\end{array}$ & $367 / 2$ weeks & 2 doses & Enoxaparin & Incidence of VTE & Underway & $\begin{array}{l}\text { Major or } \\
\text { clinically relevant } \\
\text { non-major } \\
\text { bleeding events }\end{array}$ & Underway \\
\hline
\end{tabular}


J Pharm Pharmaceut Sci (www.cspsCanada.org) 16(1) 74 - 88, 2013

\begin{tabular}{|c|c|c|c|c|c|c|c|c|}
\hline & $\begin{array}{l}\text { PEARL / phase II, } \\
\text { randomized, double- } \\
\text { blind, TKR }\end{array}$ & 685 / 6 weeks & 4 doses (od or bid) & Warfarin (INR 2-3) & Incidence of VTE & Underway & Major bleeding & Underway \\
\hline & $\begin{array}{l}\text { NCT00917254 / phase } \\
\text { II and III, randomized, } \\
\text { double-blind, TKR }\end{array}$ & $369 / 2$ weeks & $\begin{array}{l}2 \text { doses (low and } \\
\text { high) }\end{array}$ & $\begin{array}{l}\text { Enoxaparin and } \\
\text { placebo }\end{array}$ & Incidence of VTE & Underway & Bleeding events & Underway \\
\hline TAK-442 & $\begin{array}{l}\text { NCT00641732 / phase } \\
\text { II, dose finding, } \\
\text { randomized, double- } \\
\text { blind, TKR }\end{array}$ & $1038 / 10$ days & $\begin{array}{l}40 \mathrm{mg} \text { or } 80 \mathrm{mg} \\
\text { od, } 10 \mathrm{mg}, 20 \mathrm{mg} \text {, } \\
40 \mathrm{mg} \text { or } 80 \mathrm{mg} \text { bid }\end{array}$ & Enoxaparin 30mg & $\begin{array}{l}\text { Composite of DVT, } \\
\text { non-fatal PE, all- } \\
\text { cause mortality }\end{array}$ & $\begin{array}{l}39.0 \%, 38.4 \%, 23.5 \% \text {, } \\
21.4 \%, 26.8 \%, 14.3 \% \text { for } \\
10 \mathrm{mg} \text { bid, } 20 \mathrm{mg} \text { bid, } \\
40 \mathrm{mg} \text { od, } 40 \mathrm{mg} \text { bid, } \\
80 \mathrm{mg} \text { od, } 80 \mathrm{mg} \text { bid, } \\
\text { respectively, vs } 22.0 \%\end{array}$ & Major bleeding & Similar incidence \\
\hline LY517717 & $\begin{array}{l}\text { NCT00074828 / phase } \\
\text { II, randomized, double- } \\
\text { blind, TKR and THR }\end{array}$ & 511 / 6-10 days & $\begin{array}{l}25,50,75,100,125 \\
\text { and } 150 \mathrm{mg} \text { od }\end{array}$ & Enoxaparin 40mg & Incidence of VTE & $\begin{array}{l}42.3 \%, 40 \%, 54.6 \% \text {, } \\
18.8 \%, 18.8 \% \text { and } 15.6 \% \\
\text { for } 25,50,75,100,125 \\
\text { and } 150 \mathrm{mg} \text { od, } \\
\text { respectively, vs } 21.2 \%\end{array}$ & Major bleeding & $0.9 \%$ (100mg) vs $0 \%$ \\
\hline $\begin{array}{l}\text { Eribaxaban } \\
\text { (PD 0348292) }\end{array}$ & $\begin{array}{l}\text { NCT00306254 / phase } \\
\text { II, randomized, double- } \\
\text { blind, TKR }\end{array}$ & 1225 & $\begin{array}{l}0.1,0.3,0.5,1.0,2.5 \\
4.0 \text { and } 10.0 \mathrm{mg} \text { od }\end{array}$ & Enoxaparin 30mg & Incidence of VTE & $\begin{array}{l}37.1 \%, 37.1 \%, 28.8 \% \text {, } \\
19.2 \%, 14.3 \%, 1.4 \% \text { and } \\
11.1 \% \text { for } 0.1,0.3,0.5 \text {, } \\
1.0,2.5,4.0 \text { and } 10.0 \mathrm{mg} \\
\text { od, respectively, vs } \\
18.1 \%\end{array}$ & Total bleeding & $\begin{array}{l}\text { No significant dose- } \\
\text { related increase in the } \\
\text { incidence of total } \\
\text { bleeding }\end{array}$ \\
\hline
\end{tabular}

